\title{
STRUCTURAL ANALYSIS OF CHASSIS: A REVIEW
}

\author{
Suraj B Patil ${ }^{1}$, Dinesh G Joshi ${ }^{2}$ \\ ${ }^{l}$ M.E, Mechanical Engineering Department, RMD Sinhgad School of Engineering, Maharashtra, India \\ ${ }^{2}$ Assistant Professor, Mechanical Engineering Department, RMD Sinhgad School of Engineering, Maharashtra, India
}

\begin{abstract}
Nowadays, transportation industry plays major role in the economy of modern developing and industrialized countries. The goods and materials carried through heavy trucks are dramatically increasing. In this paper an effort is made to review on static structural analysis of chassis. It surveys most recent literature published within last 2 years. The review aims to provide insight into truck chassis analysis and act as a guide for researchers working on Finite Element Analysis (FEA). Truck chassis forms the structural backbone of commercial vehicle. The main function of truck chassis is to support the components and payload placed on it. There are many factors to consider while designing heavy truck chassis, material selection, strength, stiffness and weight. The present study reviewed the literature on chassis analysis and presented the findings in the subsequent sections.
\end{abstract}

Keywords: heavy trucks, chassis, finite element analysis.

\section{INTRODUCTION}

In recent few years ON- Road vehicles have changed drastically based on design and other various functional aspects. Today's continuously developing countries requires faster high load transportation in very short period of time. In order to achieve these demands, vehicle manufacturers are designing heavy load carrying vehicles. Even if these vehicles give faster heavy transportation in short time, safety of vehicle has to be ensured. Automotive chassis is frame just like skeleton on which various machine parts like engine, tires, axle, assemblies, brakes, steering etc. are bolted. It gives strength and stability to the vehicle under different conditions. The ladder frames are commonly used for heavy commercial vehicles because of their superior load carrying capacity. Frames provide strength as well as flexibility to automobile. Every vehicle has body, which has to carry not only its own weight but its payload as well.

There are various members in chassis structure main longitudinal member, end rail member and cross members. To provide a rigid, box-like structure, the cross members secure the main rails in a parallel position. The crossmembers are usually attached to side members by connection plates. The joint is riveted or bolted in truck and welded in trailers. By overall structure of any vehicle we can say that chassis is the back bone of any vehicle. If any failure occurs in chassis it will leads to collapse of whole vehicle system which cannot be replaced easily. The chassis structure must safely support the weight of the vehicle components and transmit loads that result from longitudinal, lateral and vertical accelerations that are experienced in racing environment without failure. The most significant issue in truck manufacturing industries is design of vehicles with more payload. Automotive designers need to have complete understanding of various stresses prevalent in different areas of chassis work. Hence the present work has analyzed the literature on chassis analysis and discussed the findings.

\subsection{Functions of Chassis}

- To carry load of the goods carried in the body.

- To withstand the forces caused due to the sudden braking or acceleration.

- To withstand the stresses caused due to the bad road condition.

\section{LITERATURE SURVEY}

Many researchers carried out study on truck trailer chassis and components. Madan Mohan Reddy and Lakshmi Kanta Reddy(2014)[1]investigated the modelling and analysis of container chassis using FEM to improve load carrying capacity and reducing the failure of chassis with bending by adding stiffeners. The rectangular stiffeners to be placed in between the cross members and fastened to chassis by means of bolts. The analysis results of Ansys-14 shows that there is reduction in von misses stress in chassis with stiffener up to the extent of $37.11 \%$ compared to without stiffener while stress intensity reduced up to $36.23 \%$ and deflection reduced by $36.16 \%$.

Table -1: Result

\begin{tabular}{|l|l|l|l|}
\hline & $\begin{array}{l}\text { Von } \\
\text { misses } \\
\text { stress(N/m } \\
\mathrm{m} 2)\end{array}$ & $\begin{array}{l}\text { Stress } \\
\text { Intensity(N/mm2) }\end{array}$ & $\begin{array}{l}\text { Deflection } \\
(\mathrm{mm})\end{array}$ \\
\hline $\begin{array}{l}\text { Without } \\
\text { stiffener }\end{array}$ & 1300000 & 1470000 & 9.76 \\
\hline $\begin{array}{l}\text { With } \\
\text { stiffener }\end{array}$ & 817527 & 937290 & 6.23 \\
\hline
\end{tabular}

Bhat KA, Untawale SP, Katore HV(2014)[2] redesigned the chassis for tractor trolley. The existing trolley chassis uses ' $\mathrm{C}$ ' cross section and material used is mild steel. The total capacity of the trolley is $60 \mathrm{KN}$ but the self weight of trolley and other accessories is $13 \mathrm{KN}$. Redesign is done by changing cross section from 'C'to 'I'by without change in 
material and dimension. The change in cross section resulted in more safer stresses than previous cross section and 31.79 $\mathrm{kg}$ reduction in weight, so cost of chassis ultimately reduced.

Table -2: Comparison between $\mathrm{C}$ and I cross section

\begin{tabular}{|l|l|l|}
\hline Factors & $\begin{array}{l}\text { Existing } \\
\text { 'C'section }\end{array}$ & $\begin{array}{l}\text { Suggested } \\
\text { 'I'section }\end{array}$ \\
\hline Von-misses stress & $75.452 \mathrm{Mpa}$ & $34.648 \mathrm{Mpa}$ \\
\hline Total deformation & $0.001877 \mathrm{~m}$ & $0.0002382 \mathrm{~m}$ \\
\hline Shear stress & $20.875 \mathrm{Mpa}$ & $7.5162 \mathrm{Mpa}$ \\
\hline Normal stress & $40.409 \mathrm{Mpa}$ & $13.088 \mathrm{Mpa}$ \\
\hline Mass & $431.64 \mathrm{Kg}$ & $399.85 \mathrm{Kg}$ \\
\hline
\end{tabular}

Ketan Gajanan Nalawade, Ashish Sabu and Baskar P (2014)[3] did the static structural analysis and modal analysis of a TATA 407 truck chassis. Modelling is done in CATIA and finite element analysis is done using ANSYS workbench. After carrying out the analysis on the ladder frame with structural steel and E-Glass composite the results are obtained that maximum shear stress and equivalent stress generated in E-glass is under acceptable limit and total deformation is also within the limit. It also shows that for the same load carrying capacity E- glass is more suitable than steel and thereby able to reduce the weight by $60-68 \%$ and increase in stiffness.

Abhishek Sharma, Pramod Kumar, Abdul Jabbar and Mohammad Mamoon Khan(2014)[4], have designed the heavy vehicle chassis and analyzed with the help of ANSYS-15.0. The dimension of the TATA LPS 2515 EX chassis is used for the structural analysis of the heavy vehicle chassis with three different alloys subjected to the same conditions of the steel chassis. The three material used for the chassis are grey cast iron, AISI 4130 alloy steel and ASTM A710 STEEL GRADE A (CLASS III). There are different shapes of the cross sections that were used in this work i.e. C, I and Box type cross sections. A three dimensional solid Model was built in the CATIA V5 parametric. The results shows that AISI 4130 steel alloy shows better performance and lighter than all of the other metal alloys with providing strength as well. Analysis of different cross sections shows that the box channel section is best in strength with less deformation, but weight of chassis is high compared to other cross sections while C-section chassis is suitable for heavy trucks.

Swami K.I.and Tuljapure S.B.(2014)[5] investigated the static structural analysis of truck chassis with the help of ANSYS software. Here the chassis of Eicher 20.16 is of ladder frame type which has two side members or longitudinal members of $\mathrm{C}$ - cross section and seven transverse members called cross members of $\mathrm{C}$ - cross section. The results from graph shows that as the side member thickness increases, initially there is slight decrease in the maximum value of von misses stress but afterwards it starts increasing. The rate decreases in just before the end and again increases at the end.

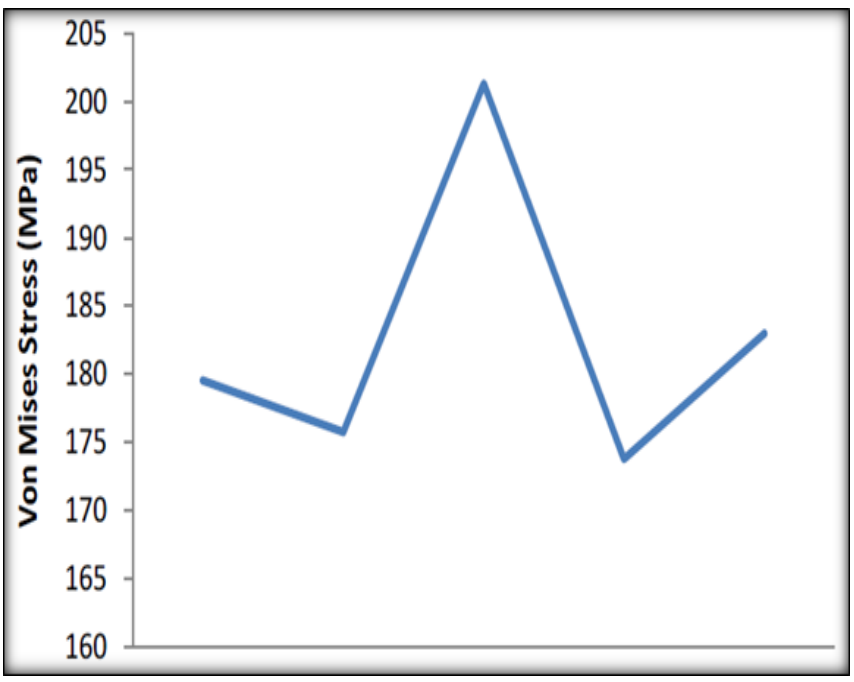

Fig -1: Side member thickness Vs maximum Von misses stress of ladder chassis.

Structural analysis of vehicle chassis with constraints of maximum shear stress and deflection of chassis under maximum load through using Pro-e 4.0 and Altair Hyperworks software was performed by Abhishek Singh, Vishal Soni, Aditya Singh (2014)[6] . The dimensions of vehicle chassis of a TATA LP 912 Diesel BS4 bus was taken for analysis with materials namely Steel alloy subjected to the same load. The four different vehicle chassis have been modeled by considering four different cross-sections. Namely C, I, Rectangular Box (Hollow) and Rectangular Box (Intermediate) type cross sections. From the results, it was observed that the Rectangular Box (Intermediate) section is more strength full than the conventional steel alloy chassis with C, I and Rectangular Box (Hollow) section design specifications. The Rectangular Box section was having least deflection in all the four type of chassis of different cross section.

Table -3: Comparative Analysis of Different Chassis

\begin{tabular}{|l|l|l|l|l|}
\hline $\begin{array}{l}\text { Sr. } \\
\text { No }\end{array}$ & Cross-sections & $\begin{array}{l}\text { Displac } \\
\text { ement } \\
(\mathbf{m m})\end{array}$ & $\begin{array}{l}\text { VonMises } \\
\text { Stress } \\
(\mathbf{M p a})\end{array}$ & $\begin{array}{l}\text { Max. } \\
\text { Shear } \\
\text { Stress } \\
(\mathbf{M p a})\end{array}$ \\
\hline 1 & C-Type & 6.153 & $3.01 \times 10^{2}$ & $1.59 \times 10^{2}$ \\
\hline 2 & I-Type & 4.786 & $2.34 \times 10^{2}$ & $1.24 \times 10^{2}$ \\
\hline 3 & $\begin{array}{l}\text { Rectangular } \\
\text { Box (Hollow) } \\
\text { Type }\end{array}$ & 2.683 & $1.27 \times 10^{2}$ & $6.53 \times 10^{1}$ \\
\hline 4 & $\begin{array}{l}\text { Rectangular } \\
\text { Box } \\
\text { (Intermediate) } \\
\text { Type }\end{array}$ & 1.839 & $1.12 \times 10^{2}$ & $5.81 \times 10^{1}$ \\
\hline
\end{tabular}


Sandip Godse and D.A.Patel(2013) [7] presents the paper on static load analysis of the chassis of TATA ace ex using ANSYS workbench and stress optimization using reinforcement technique of optimization. This has been carried out with limited modifications by adding stiffeners. They analyzed the existing chassis by the finite element analysis, the stress levels are found to be $37.04 \mathrm{~N} / \mathrm{mm}^{2}$. After modifications, the chassis with suitable reinforcement, increase in thickness, addition of stiffeners, the finite element analysis was carried out, and the stress levels of chassis are found as $22.97 \mathrm{~N} / \mathrm{mm}^{2}$ which demonstrates that the modified chassis is capable to carry the loads beyond the previous payload.

Manpreet Singh Bajwa, Yatin Raturi and Amit Joshi (2013)[8] investigated static load analysis of TATA ACE chassis using ANSYS Workbench and verification has been done using solid mechanics. Here the chassis is of ladder frame type which has two side members or longitudinal members of $\mathrm{C}$ - cross section and five transverse members called as cross members of box cross section. The chassis has been modelled in CATIA V5R18 using the most of the actual dimensions. Result shows that static analysis and verification has successfully done using solid mechanics.

Mohd Azizi Muhammad Nora, Helmi Rashida, Wan Mohd Faizul ,Wan Mahyuddin, Mohd Azuan Mohd Azuan,Jamaluddin Mahmud (2012)[9] performs the stress analysis of an actual low loader structure consisting of Ibeams design application of 35 ton trailer. Modeling is done in CATIA V5R18. The results of analysis revealed that the location maximum deflection and maximum stress agrees well with theoretical maximum location of simple beam under uniform loading distribution. It also shows that maximum stress is $571.4 \mathrm{Mpa}$ on beam A.This study found out that there is discrepancy between the theoretical (2-D) and numerical (3-D FEA) results. It is observed that the maximum deflection is pointed in situated in between $\mathrm{BC} 1$ and BC2 with magnitude of $7.79 \mathrm{~mm}$.

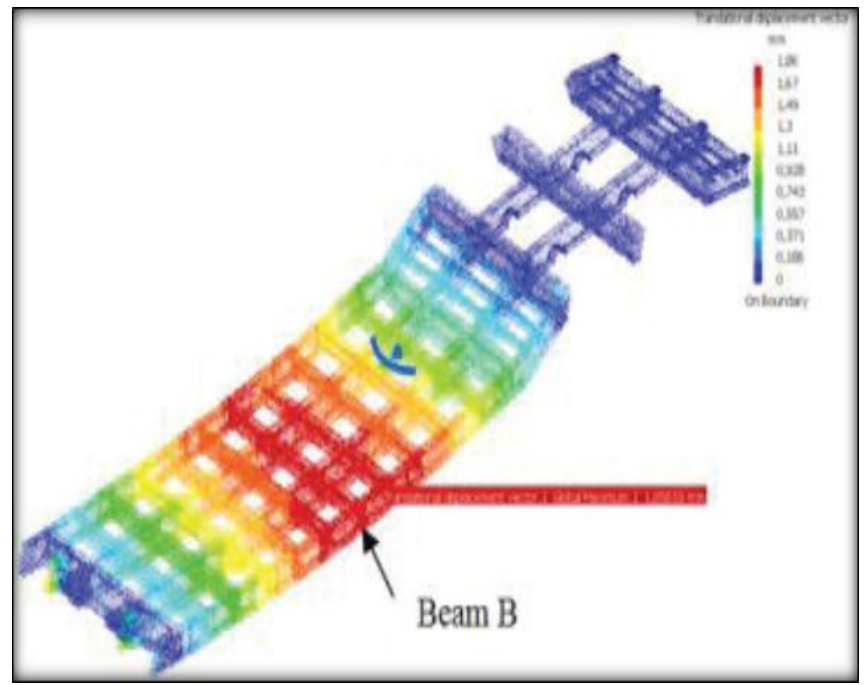

Fig -2: Maximum deflection observed on beam.

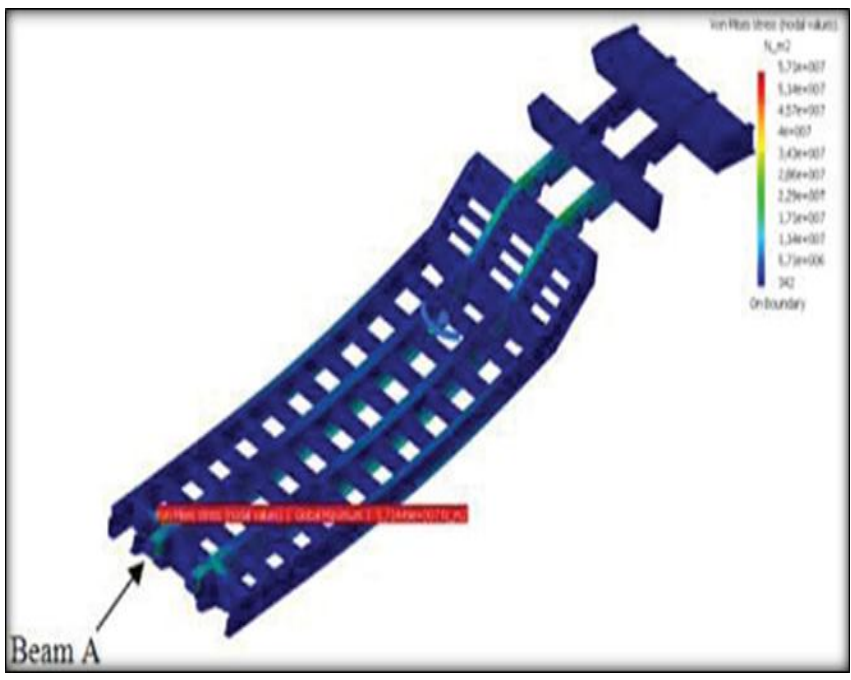

Fig -3: Maximum Von Misses Stress on the chassis.

Vijaykumar V. Patel, R. I. Patel (2012)[10] have studied the Ladder chassis frame of Eicher E2 by static structural analysis. For this study chassis was assumed as simply supported beam with overhang. Pro-E and Ansys software were used for this work. The study also involved the analytical calculation of chassis. Both software analysis and analytical calculation results were compared and found that the stress value obtained from software analysis is $10 \%$ more and also displacement was $5.92 \%$ more.

\section{CONCLUSION}

In this paper review of static structural analysis of chassis is presented. It is observed that most of the existing researchers utilized common FEA package ANSYS, while very less used packages are ABAQUS, NASTRAN, HYPERVIEW. After a careful analysis of various research studies conducted so far it has been found that sufficient studies have not been conducted on variable section concept and trailer chassis. Hence in order to fill the gap future research studies may be conducted on variable section chassis and trailer chassis concept in automobile.

\section{ACKNOWLEDGEMENTS}

I am very thankful to my project guide Prof. Dinesh G. Joshi, Assistant professor, Mechanical Engineering Department, RMD Sinhgad School of Engineering, Warje Pune, for his continuous support and encouragement in completing this work.

\section{REFERENCES}

[1]. Madan Mohan Reddy and Lakshmi Kanta Reddy, "Modeling and Analysis of container chassis using FEM", International Organization of Scientific Research Journal of Engineering(IOSRJEN), Vol. 04, Issue 01 (January. 2014), pp. 34-37.

[2]. Bhat KA, Untawale SP, Katore HV, "Failure Analysis And optimization of Tractor Trolley Chassis: An Approach Using Finite Element Analysis", International Journal of Pure and Applied Research In Engineering And Technology(IJPRET), 2014; Vol.2 (12), pp.71-84 . 
[3]. Ketan Gajanan Nalawade, Ashish Sabu, Baskar P, "Dynamic (Vibrational) and Static Structural Analysis of Ladder Frame", International Journal of Engineering Trends and Technology (IJETT) - Vol.11 Number 2 - May 2014,ISSN:2231-5381,pp.93-98.

[4]. Abhishek Sharma, Pramod Kumar, Abdul Jabbar and Mohammad Mamoon Khan, "Structural Analysis of a Heavy Vehicle Chassis Made of Different Alloys by Different Cross Sections", International Journal of Engineering Research \& Technology (IJERT), Vol. 3 Issue 6, June - 2014, pp.1778-1785.

[5]. Swami K.I.and Tuljapure S.B, "Analysis of Ladder Chassis of Eicher 20.16 Using FEM", IOSR Journal of Applied Geology and Geophysics (IOSR-JAGG), Vol. 2, Issue 1 Ver. I. (Jan. 2014), pp.06-13.

[6]. Abhishek Singh, Vishal Soni, Aditya Singh, "Structural Analysis of Ladder Chassis for Higher Strength", International Journal of Emerging Technology and Advanced Engineering(IJETAE), Vol. 4, Issue 2, Feb 2014, pp.254-259.

[7]. Sandip Godse and D.A.Patel, "Static Load Analysis Of Tata Ace Ex Chassis And Stress Optimisation Using Reinforcement Technique", International Journal of Engineering Trends and Technology( IJETT), Vol.4, Issue7July 2013, pp. 3037-3039.

[8]. Manpreet Singh Bajwa, Yatin Raturi and Amit Joshi, "Static Load Analysis of TATA Super Ace Chassis and Its Verification Using Solid Mechanics", International Journal of Mechanical and Production Engineering(IJMPE), Vol. 1, Issue- 2, Aug-2013,pp.55-58.

[9]. Mohd Azizi Muhammad Nora, Helmi Rashida, Wan Mohd Faizul, Wan Mahyuddin, Mohd Azuan Mohd Azuan,Jamaluddin Mahmud, "Stress Analysis of a Low Loader Chassis", Elsevier Ltd. Sci Verse Science Direct Procedia Engineering 41 ( 2012 ), pp. 995 - 1001.

[10]. Vijaykumar V. Patel, R. I. Patel, "Structural analysis of a ladder chassis frame', World Journal of Science and Technology, Vol.2, pp.05-08, 2012.

\section{BIOGRAPHIES}

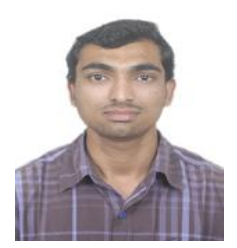

Mr. Suraj B. Patil, have completed my B.E. with distinction class from SITS Narhe, Pune, Maharashtra. Presently studying in $\mathrm{II}^{\text {nd }}$ Year M.E.(Design Engineering) from University of Pune.

Email-id: spatil14791@gmail.com

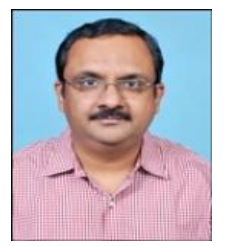

Prof. Dinesh G. Joshi, Department of Mechanical engineering, RMD Sinhgad School of Engineering, Warje Pune.

Email-id: ojujoshi@gmail.com 